assume that all celluloses are identical in every respect.

Chemistry Department,

E. G. V. Percival

Alan G. Ross

King's Buildings,

University, Edinburgh 9. July 1.

'Stanford, J. Soc. Chem. Ind., 4, 518 (1885).

"Atsuki and Tomoda, Chem. Abstr., 21, 115 (1927). Ricard, Bull. Soc. Chim. Biol., 13, 417 (1931).

Kylin, Z. physiol. Chem., 94, 337 (1915).

- Russell-Wells, Nature, 133, 651 (1934).

'Dillon and O'Tuama, Sci. Proc. Roy. Dublin Soc., 21, 147 (1935).

"Methods of Analysis" (Assoc. Off. Agr. Chem. Washington, 1935).

'Clibbens and Little, J. Text. Inst., 27, 285 (1936).

${ }^{8}$ Monier-Williams, J. Chem. Soc., 119, 803 (1921).

- Somogyi, J. Biol. Chem., 100, 695 (1933).

${ }^{10}$ Harding and Selby, Biochem. J., 1815 (1931).

"Hibbert and Barsha, Can. J. Res., 10, 178 (1934).

12 Brown, Dunstan, Halsall, Hirst and Jones, Nature, 156, 785 (1945).

\section{Effect of 5-Alkyl (Benzyl) Derivatives of 2-Thio-4-Methyl-Uracil on the Thyroid Gland and the Bone Marrow in Rabbits}

H. Cullumbine and M. Simpson ${ }^{1}$ have reported the results of their investigations on the activity of several derivatives of thymine (5-methyl-uracil) having an antithyroid property and a stimulating action on the bone marrow. These researches were based on the assumption that if thymine, according to Spiess, Jacobson and Williams, possesses a thera. peutic value in the treatment of pernicious anæmia, its thio-derivatives should have a similar property with the simultaneous antithyroid activity. It is known that one of the greatest disadvantages of antithyroid drugs now being used is their toxic effect on the functioning of the bone marrow. The quantitative changes of reticulocytes and leucocytes in normal and splenectomized rabbits after a parenteral treatment with the compounds being tested were the basis of Cullumbine and Simpson's investigations.

The thiouracil derivatives synthesized by me in the Biological Institute of the University of Krakow possessed various hydrocarbon radicals $(R)$ in position 5 beside the methyl grouping in position 4 .

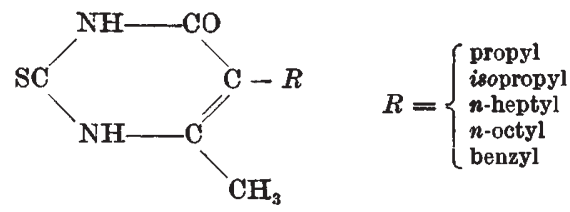

These compounds were examined biologically in regard to their action on the histological picture of the thyroid gland and to their influence on the functioning of the bone marrow. The criterion of the latter in my work was the number of white blood cells in $1 \mathrm{~mm} .^{3}$. The animals used were white rabbits about eight weeks old. All the compounds tested were given by mouth in equal dosages, once daily and for equal periods, to facilitate the comparison of the results obtained. The animals were treated in three groups: group (I), 9 days with $50 \mathrm{mgm}$. a day; group (II), 9 days with $50 \mathrm{mgm}$. a day and the following 5 days with $100 \mathrm{mgm}$. a day; group (III), 9 days with $50 \mathrm{mgm}$. a day and the following 9 days with $150 \mathrm{mgm}$. a day. In this way the following compounds were tested biologically : 2-thio-4-methyl- uracil ; 2-thio-4-methyl-5-propyl-uracil ; 2-thio-4methyl-5-n-heptyl-uracil ; 2-thio-4-methyl-5-n-octyluracil ; 2-thio-4-methyl-5-isopropyl-uracil; and 2thio-4-methyl-5-benzyl-uracil.

The first compound (May and Baker, Ltd.), at present widely used in the treatment of all forms of thyroid hyperfunction, was used as a standard preparation for comparison purposes. The results are given in the accompanying table.

\begin{tabular}{|l|c|c|}
\hline Name of compound & $\begin{array}{c}\text { Average percent- } \\
\text { age change in } \\
\text { white blood cell } \\
\text { count }\end{array}$ & $\begin{array}{c}\text { Histological } \\
\text { activity }\end{array}$ \\
\hline $\begin{array}{l}\text { 2-Thio-4-methyl-5-propyl-uracil } \\
\text { 2-Thio-4-methyl-5-nheptyl-uracil } \\
\text { 2-Thio-4-methyl-5-n-octyl-uracil }\end{array}$ & $\begin{array}{c}-30 \\
+64 \\
+66\end{array}$ & $\begin{array}{c}+++ \\
\text { no effect } \\
\text { no effect }\end{array}$ \\
\hline $\begin{array}{l}\text { 2-Thio-4-methyl-5-isopropyl- } \\
\text { uracil }\end{array}$ & +52 & + \\
2-Thio-4-methyl-5-benzyl-uracil & +15 & + \\
\hline 2-Thio-4-methyl-uracil & -28 & ++++ \\
\hline
\end{tabular}

Comparing the results, it is clear that the greater the number of carbon atoms in the $n$-radical linked with position 5, and consequently the larger the molecular weight of the whole compound, the weaker its antithyroid activity and the greater the stimulating effect on the bone marrow. The decrease of the antithyroid activity in this group of derivatives is, I think, connected with the increase of the molecular weight of the compounds, and consequently with decrease of the percentage of sulphur in the molecule.

In the second group of compounds tested there is an interesting difference between the 2-thio-4methyl-5-propyl-uracil and 2-thio-4-methyl-5-isopropyl-uracil. The former exerts a marked influence on the function of the thyroid gland and an inhibiting one on the bone marrow, whereas the latter with its small effect on the thyroid gland brings about a rise of the white blood cells count of about 52 per cent.

Of the aromatic derivatives of 2-thio-4-methyluracil only the benzyl compound was tested; it was found to be ineffective as regards both the thyroid and the bone marrow.

These results show that the pharmacological action of these compounds depends not only on the number of the carbon atoms but also on the configuration of the radical linked with position 5. Further derivatives of this type are being prepared and tested.

Institute of Biology and Embryology, ARThuR JURAND

$$
\text { Cullumbine, H., and Simpson, M., Nature, 159, } 680 \text { (1947). }
$$

\section{Role of Gastric Urease}

IN a previous communication ${ }^{1}$, we were able to confirm that urease is present in the gastric mucosa and, to some extent, in the duodenal mucosa. It was pointed out that the amount of the ferment present in the whole stomach of an animal is sufficient to release enough ammonia from urea to neutralize large amounts of hydrochloric acid.

We suggested previously that urease might be concerned with the protection of the superficial gastric mucosa and the neutralization of hydrochloric acid, a view of its possible purpose which has also been advanced in the past by Luck ${ }^{2}$, Linderstrøm-Lang and Ohlsen ${ }^{3}$ and others. No direct experiments on this point were ever apparently made. If the con. centrations of the substrate, urea, were changed, 